\title{
A study of lightning activity over land and oceanic regions of India
}

\author{
Asha Nath ${ }^{1}$, G K Manohar ${ }^{2}, \mathrm{~K} \mathrm{~K} \mathrm{DAni}^{1}$ and P C S Devara ${ }^{1}$ \\ ${ }^{1}$ Indian Institute of Tropical Meteorology, Pune 411 008, India. \\ ${ }^{2}$ Formerly, Indian Institute of Tropical Meteorology, Pune 411 008, India.
}

\begin{abstract}
Monthly variations of lightning activity over typical land and oceanic regions of India were examined using satellite data (OTD) for a 5-year period (1995-1999). It is noted that the nature of variation between surface air maximum temperature $\left(T_{\max }\right)$, thunderstorm days $\left(\mathrm{Th}_{\mathrm{n}}\right)$, and lightning flash count over ER and WR showed remarkable correspondence and sensitivity with each other on monthly time scale. As we move out of winter season and enter the monsoon season, via pre-monsoon season, the WR undergoes cooling relative to the ER in the range $0.1-1.2^{\circ} \mathrm{C}$. As a result, WR experiences reduction of thunder days and lowering in flash count. This decrease in $T_{\max }, \mathrm{Th}_{\mathrm{n}}$, and flash count over WR may also be associated with relatively small values of $T_{\theta w}$ and CAPE in comparison with similar values over ER during the monsoon season. Our observation of associated reduction in $\mathrm{Th}_{\mathrm{n}}$ and lightning count per $1^{\circ} \mathrm{C}$ cooling in surface air maximum temperature suggests reduction of $\sim 3.5$ thunderstorms per station and 73 flashes. Comparison of lightning flashes between pairs of coastal, oceanic, arid-zone, hilly, and island stations reveals distinct relationship between climate regime and intensity of lightning activity. We may conclude the results of this study by saying that the overhead lightning activity is a clear reflection of the status of the underlying ground-earth properties. A close and continuous monitoring of lightning activity may be considered as a need of present day scientific studies.
\end{abstract}

\section{Introduction}

We live in the earth's environment which is constantly electrified. The knowledge of this important property of the atmosphere was truly sought only from the observation of a flash of lightning from a thundercloud. Otherwise, in the absence of a flash, in fair weather condition, it is nearly impossible to know that the earth's atmosphere is filled with electric currents. Lightning has played decisive role in the fixation of atmospheric $\mathrm{NO}_{\mathrm{X}}$ and development of precipitation per lightning flash at the ground, and hence it is understood as a resourceful and essential natural phenomenon of great importance. These attributes of lightning are evident from many early and recent studies (Smyth 1907; Workman and
Reynolds 1949; Jones 1958; Malan 1958; Schonland 1964; Newcott 1993; Borucki and Chameides 1984; Pradeepkumar et al 1995; Petersen and Rutledge 1996) devoted to lightning research. With the progress in time, global lightning observations from satellite and also from the deployment of Schumann Resonance technique, have poured in large number for studies (Williams 1992; Nickolaenko and Rabinowicz 1995; Satori and Zieger 1996; Williams et al 2000; Boccipio et al 2000b; Williams and Stanfill 2002). From the results of above studies, it is apprarent that the approach towards lightning studies in the early years was more academic, while the approach during the recent decade has been relevant to practical applications of the subject. Many of these studies suggest that their emphasis is more on the application aspects of

Keywords. Lightning; thunderstorm; seasonal variation. 
lightning knowledge to climate related issues. For example:

- Lightning activity increases dramatically with the depth and vigour of convection over land and is dominant in the tropics (Orville and Hendersen 1986; Williams 1985);

- Approximately, two of every three flashes occur in the tropical belt: $\pm 23^{\circ}$;

- Lightning observations from space revealed that tropical land areas exhibit substantially more lightning than do the central oceans. The landocean contrast in lightning activity is also one such front line topic.

From the above discussion, it may be inferred that lightning over land, over oceanic areas, over latitude belts, and over vivid climate regimes behaves differently. Over the Indian region, land and sea waters are juxtaposed to produce weather during major time (March-October) of the annual period. Also, India is gifted with the availability of varied climate zones such as semi-arid, coastal, island, hilly, inland and oceanic. Studies on lightning activity over different parts of India are infrequent (Aiya 1968; Boeck et al 1999; Manohar and Kandalgaonkar 1995; Manohar et al 1999; Kandalgaonkar et al 2003; 2005a, 2005b; 2006a, 2006b). Therefore, there is sufficient scope for the study of lightning activity over such locations. This work forms a case study of lightning activity over typical land-land and land-oceanic regions of India.

\section{Data and method of analysis}

The Optical Transient Detector system (OTD) is a highly compact combination of optical and electronic elements. The OTD can gather lightning data under daytime conditions as well as at night. The OTD is a satellite-borne instrument and has been in operation in the low earth orbit since April 1995. The OTD revolves round the earth orbit at an altitude of $\sim 710 \mathrm{~km}$ with an inclination of 70 degrees with respect to the equator. With that orbit and a field of view of 100 degrees, it surveys nearly all areas of the globe where lightning normally occurs.

The typical observation time of OTD instrument over any given location is 2-3 minutes. This observation time is adequate to determine an instantaneous thunderstorm flash rate. OTD sees latitudes up to $\pm 70^{\circ}$ and beyond. The OTD takes $\sim 55$ days to come to its original position. OTD observations enable objective measurements of thunderstorms and provide flash count information in the tropics and extra-tropics. OTD has a spatial resolution of $10 \mathrm{~km}$ and time resolution of $2 \mathrm{~ms}$. More technical details and observation information can be found in Christian et al (1996) and Williams et al (2000). Boccippio et al (2000a) used lightning data from the U.S. National Lightning Detection Network (NLDN) to perform preliminary validation of the satellite-based OTD. Sensor precision, accuracy, detection efficiency, and biases of the deployed instrument were considered in their study. The sensor is estimated to have, on average, about $20-40 \mathrm{~km}$ spatial and better than $100-\mathrm{ms}$ temporal accuracy. The detection efficiency for cloud-to-ground lightning is about $46-69 \%$. A data retrieval algorithm for validating OTD was developed by Koshak et al (2000), which was found to be sufficiently accurate.

Global or regional lightning activity is a highly variable parameter on many time-scales. This variability is usually attributable to changes in flash rate per thunderstorm, and also to the number of thunderstorms themselves. It is reported (Williams et al 2000) that among the above factors, the contribution of number of thunderstorms is 2-3 times greater than that of the changes in lightning flash rate of an individual storm. In a recent study concerning thunderstorms over Indian region, Manohar and Kesarkar (2003) have pointed out a strong gradient in thunderstorm activity between the eastern and western regions of India. It is also mentioned that the strong gradient in thunderstorm activity is more or less a regular feature, which is attributable to differences in properties of many geophysical parameters (i.e., Bowen ratio, soil properties, vegetation, altitude above mean sea level, etc.) over the ER and WR. Further, it is known that the thunderstorms are the best known principal source of lightning activity. This important point and above results have strongly motivated us to take up the study of land-land and land-ocean contrast in lightning activity over India.

The geographic regions of India chosen for the present study include:

- Eastern region (ER) and western region (WR) of India,

- East coast of India and a strip of six oceanic locations, $110 \mathrm{~km}$ away from the east coast and located in the Bay of Bengal,

- West coast of India and a strip of six oceanic locations, $110 \mathrm{~km}$ away from the west coast and located in the Arabian Sea,

- Island stations, Port Blair and Minicoy,

- Two land stations: Jaisalmer (JSM) and Ahmedabad (AHM) situated in the semi-arid zone of NW India, and two land stations: Guwahati (GHT) and Agartala (AGT) situated in the hilly region of NE India. 
Map of India

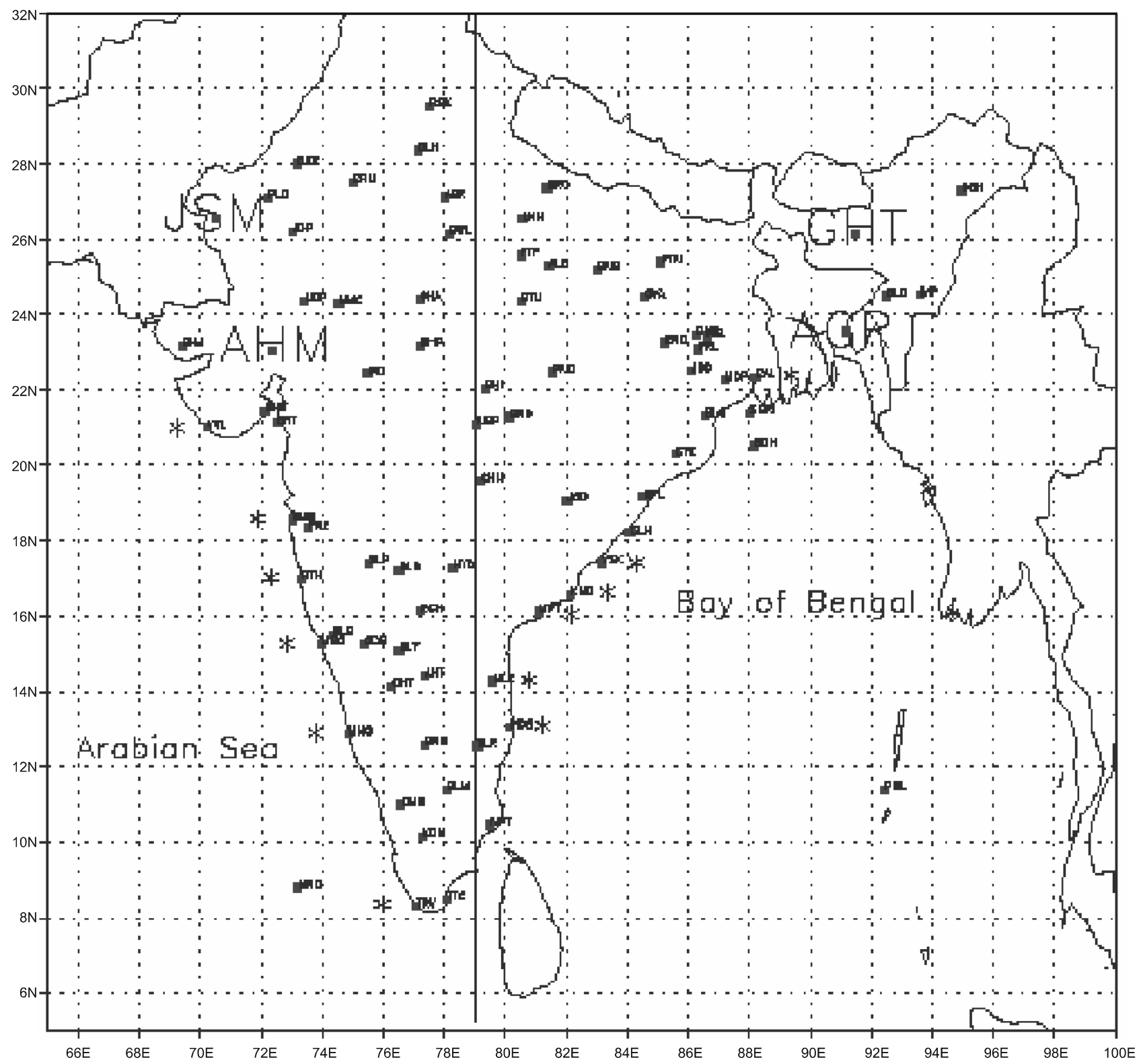

Figure 1. Map of India and the network of 66 land stations, six coastal stations each on ER and WR, two island stations (Portblair (PBL) and Minicoy (MNC)), and six oceanic locations each off the two coasts of India. The off-coast locations are $110 \mathrm{~km}$ away from the coasts and are shown by the asterisk symbol.

This study mainly concentrates on:

- comparison between monthly (JanuaryDecember) mean values of lightning counts over the two largest land regions: ER and WR,

- study of surface temperature and thermodynamic structure over ER and WR,

- occurrence of thunderstorms and development of lightning in relation to temperature change of surface air,

- comparative study of lightning flash count between pairs of above-mentioned typical land/ oceanic regions of India, and
- a correspondence between lightning flash count and climate regimes over India.

Figure 1 shows the map of India and the location of 66 land stations, six stations each on east and west coasts, two island stations \{Portblair (PBL) and Minicoy (MNC)\}, and six oceanic locations each off the two coasts of India. Off-the coast locations are $110 \mathrm{~km}$ away from the coasts and are shown with asterisk mark. Table 1 presents some details of land and island stations considered in the present study. The daily lightning data recorded by the OTD for 5-year period (1995-1999) 
Table 1. Some particulars of the stations used in this study.

\begin{tabular}{|c|c|c|c|c|c|}
\hline $\begin{array}{l}\text { Sl. } \\
\text { no. }\end{array}$ & Station & Abbreviation & $\begin{array}{l}\text { Latitude }(\mathrm{N}) \text {, } \\
\text { deg. and min }\end{array}$ & $\begin{array}{c}\text { Longitudes }(\mathrm{E}) \text {, } \\
\text { deg. and min }\end{array}$ & $\begin{array}{c}\text { Height } \\
\text { above } \mathrm{msl}(\mathrm{m})\end{array}$ \\
\hline 1 & Agartala & AGT & $23 \quad 53$ & $91 \quad 15$ & 16 \\
\hline 2 & Agra & AGR & $27 \quad 10$ & $\begin{array}{ll}78 & 02\end{array}$ & 169 \\
\hline 3 & Ahmedabad & AHM & 2304 & 7238 & 55 \\
\hline 4 & Allahabad & ALB & $25 \quad 27$ & 8144 & 98 \\
\hline 5 & Anantpur & $\mathrm{ANT}$ & 1441 & $\begin{array}{ll}77 \quad 37\end{array}$ & 350 \\
\hline 6 & Asansol & ASL & 2341 & $86 \quad 59$ & 96 \\
\hline 7 & Bahraich & $\mathrm{BRC}$ & $27 \quad 34$ & 8136 & 124 \\
\hline 8 & Balasore & BLS & 2130 & $86 \quad 56$ & 20 \\
\hline 9 & Banaras & BNS & 2518 & 8301 & 76 \\
\hline 10 & Bangalore & BNG & 1258 & $77 \quad 35$ & 921 \\
\hline 11 & Belgaum & BLG & 1551 & $74 \quad 32$ & 753 \\
\hline 12 & Bellary & BLY & 1509 & $76 \quad 51$ & 747 \\
\hline 13 & Bhavnagar & $\mathrm{BHV}$ & 2145 & 7211 & 11 \\
\hline 14 & Bhopal & BHP & $23 \quad 17$ & $\begin{array}{ll}77 & 21\end{array}$ & 523 \\
\hline 15 & Bhuj & BHJ & $23 \quad 15$ & 6940 & 80 \\
\hline 16 & Bikaner & BKR & 2800 & $\begin{array}{ll}73 & 18\end{array}$ & 224 \\
\hline 17 & Bombay & BMB & $18 \quad 54$ & $72 \quad 49$ & 11 \\
\hline 18 & Calcutta & $\mathrm{CAL}$ & 2232 & $88 \quad 20$ & 6 \\
\hline 19 & Chandrapur & $\mathrm{CHN}$ & 1958 & $\begin{array}{ll}79 & 18\end{array}$ & 193 \\
\hline 20 & Chitradurga & $\mathrm{CHT}$ & 1414 & $\begin{array}{ll}76 \quad 28\end{array}$ & 733 \\
\hline 21 & Churu & $\mathrm{CRU}$ & $27 \quad 50$ & 7500 & 291 \\
\hline 22 & Coimbatore & CMB & 1100 & $\begin{array}{ll}76 & 58\end{array}$ & 409 \\
\hline 23 & Cuttack & CTK & 2028 & $85 \quad 56$ & 27 \\
\hline 24 & Dhanbad & DNB & $23 \quad 47$ & $86 \quad 26$ & 257 \\
\hline 25 & Dibrugarh & $\mathrm{DBH}$ & $27 \quad 28$ & 9495 & 111 \\
\hline 26 & Fatehpur & FTP & $25 \quad 56$ & $80 \quad 50$ & 114 \\
\hline 27 & Gadag & GDG & 1525 & 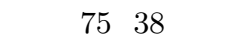 & 650 \\
\hline 28 & Guwahati & GHT & 2611 & 9145 & 54 \\
\hline 29 & Gaya & GYA & $24 \quad 45$ & $84 \quad 57$ & 116 \\
\hline 30 & Gondia & GND & 2128 & $80 \quad 12$ & 313 \\
\hline 31 & Gopalpur & GPL & 1916 & $84 \quad 53$ & 17 \\
\hline 32 & Gulbarga & GLB & $17 \quad 21$ & $76 \quad 51$ & 458 \\
\hline 33 & Guna & GNA & 2439 & $\begin{array}{ll}77 & 19\end{array}$ & 478 \\
\hline 34 & Gwalior & GWL & 2614 & $78 \quad 15$ & 207 \\
\hline 35 & Hyderabad & HYD & 1727 & $78 \quad 28$ & 545 \\
\hline 36 & Imphal & IMP & 2451 & 9358 & 781 \\
\hline 37 & Indore & IND & 2243 & $75 \quad 48$ & 567 \\
\hline 38 & Jagdalpur & JGD & 1905 & $82 \quad 02$ & 553 \\
\hline 39 & Jaisalmer & JSM & 2654 & $70 \quad 55$ & 242 \\
\hline 40 & Jamshedpur & JSD & 2249 & 8611 & 129 \\
\hline 41 & Jodhpur & JDP & $26 \quad 18$ & $\begin{array}{ll}73 & 01\end{array}$ & 217 \\
\hline 42 & Kakinada & KND & 1657 & 8214 & 8 \\
\hline 43 & Kalingapatnam & CLN & 1820 & 8408 & 6 \\
\hline 44 & Kodaikanal & KDK & 1014 & $\begin{array}{ll}77 & 28\end{array}$ & 2343 \\
\hline 45 & Lucknow & $\mathrm{LKN}$ & $26 \quad 52$ & $80 \quad 56$ & 128 \\
\hline 46 & Machalipatnam & MPT & 1611 & 8108 & 3 \\
\hline 47 & Madras & MDS & 1304 & $80 \quad 15$ & 16 \\
\hline 48 & Mangalore & MNG & 1287 & 7485 & 22 \\
\hline 49 & Marmagao & MRG & 1525 & 7347 & 62 \\
\hline 50 & Midnapur & MDP & $22 \quad 25$ & $87 \quad 19$ & 45 \\
\hline 51 & Minicoy & $\mathrm{MNC}$ & 818 & 73 & 2 \\
\hline 52 & Nagapatnam & NPT & 1046 & 7951 & 9 \\
\hline 53 & Nagpur & NGP & 2109 & $\begin{array}{ll}79 & 07\end{array}$ & 310 \\
\hline 54 & Neemuch & $\mathrm{NMC}$ & $24 \quad 28$ & $74 \quad 54$ & 496 \\
\hline
\end{tabular}


Table 1. (Continued).

\begin{tabular}{|c|c|c|c|c|c|}
\hline $\begin{array}{l}\text { Sl. } \\
\text { no. }\end{array}$ & Station & Abbreviation & $\begin{array}{l}\text { Latitude }(\mathrm{N}) \text {, } \\
\text { deg. and min }\end{array}$ & $\begin{array}{c}\text { Longitudes (E), } \\
\text { deg. and min }\end{array}$ & $\begin{array}{c}\text { Height } \\
\text { above } \mathrm{msl}(\mathrm{m})\end{array}$ \\
\hline 55 & Nellore & NLR & 1427 & 7959 & 20 \\
\hline 56 & New Delhi & DLH & $28 \quad 35$ & $\begin{array}{ll}77 & 12\end{array}$ & 216 \\
\hline 57 & Patna & PTN & $25 \quad 37$ & $85 \quad 10$ & 60 \\
\hline 58 & Pendra & PND & 2246 & 8154 & 625 \\
\hline 59 & Phalodi & PLD & 2708 & $72 \quad 22$ & 234 \\
\hline 60 & Port Blair & PBL & 1140 & 9243 & 79 \\
\hline 61 & Pune & PNE & 1832 & 7351 & 559 \\
\hline 62 & Purulia & PRL & 2306 & $86 \quad 30$ & 255 \\
\hline 63 & Raichur & $\mathrm{RCH}$ & 1612 & $\begin{array}{ll}77 & 21\end{array}$ & 400 \\
\hline 64 & Ranchi & $\mathrm{RNC}$ & 2323 & $85 \quad 20$ & 652 \\
\hline 65 & Ratnagiri & RTN & 1698 & $73 \quad 33$ & 67 \\
\hline 66 & Roorkee & RRK & 2951 & $77 \quad 53$ & 274 \\
\hline 67 & Sagar Island & SGRI & 2139 & $88 \quad 03$ & 3 \\
\hline 68 & Salem & SLM & 1139 & $78 \quad 10$ & 278 \\
\hline 69 & Sandheads & $\mathrm{SDH}$ & 2051 & $88 \quad 15$ & 10 \\
\hline 70 & Satna & $\mathrm{STN}$ & 2434 & $80 \quad 50$ & 317 \\
\hline 71 & Seoni & SNI & 2203 & 7933 & 619 \\
\hline 72 & Silchar & SLC & $24 \quad 49$ & 9248 & 29 \\
\hline 73 & Solapur & SLP & 1740 & $75 \quad 54$ & 479 \\
\hline 74 & Surat & SRT & $21 \quad 12$ & 7250 & 12 \\
\hline 75 & Thiruvananthapuram & TRV & 829 & $76 \quad 57$ & 64 \\
\hline 76 & Tuticorin & TTC & 848 & $\begin{array}{ll}78 & 09\end{array}$ & 4 \\
\hline 77 & Udaipur & UDP & 2435 & 7342 & 582 \\
\hline 78 & Vellore & VLR & 1255 & 7909 & 214 \\
\hline 79 & Veraval & VVL & 2054 & $70 \quad 22$ & 8 \\
\hline 80 & Visakhapatnam & VSK & 1741 & 8318 & 3 \\
\hline
\end{tabular}

were obtained at spatial resolution of $0.5^{\circ} \times 0.5^{\circ}$ $(\sim 55 \times \sim 55 \mathrm{~km})$ for all these locations.

To examine contrast in lightning activity over $\mathrm{ER}$ and WR, following the work of Manohar and Kesarkar (2003), India is demarcated by the $79^{\circ} \mathrm{E}$ longitude line drawn from south to north (see figure 1). It is believed that the demarcation of India in ER and WR, both contain equal number of stations, is quite suitable and logically appropriate for undertaking this analysis. Results of monthly mean values of lightning flash count at the abovementioned six geographic regions are described in the following section.

\section{Results and discussion}

\subsection{Comparison of lightning flash count between eastern region ( $E R$ ) and western region (WR) of India: A documentation of east-west contrast}

Monthly mean variation of lightning flash count over ER and WR of India is shown in figure 2. Monthly and seasonal means of lightning flash count, $\mathrm{Th}_{\mathrm{n}}$ and $T_{\max }$ over ER and WR are also

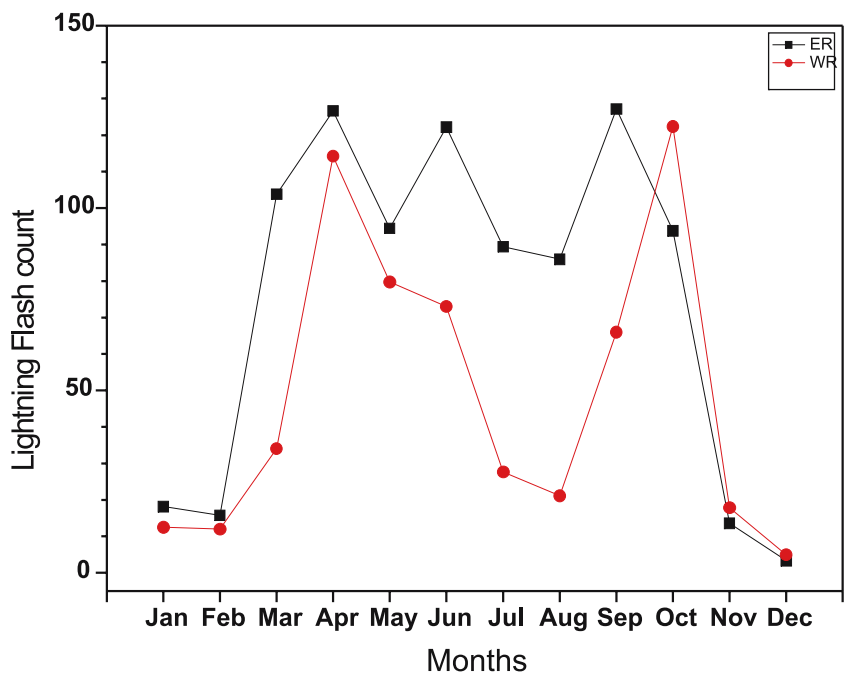

Figure 2. Monthly mean variation of lightning flash count over ER and WR of India: i.e., over the two largest land regions of India demarcated by $79^{\circ} \mathrm{E}$ longitude line.

furnished in table 2 for the convenience of quick reference. A careful examination of the plots in figure 2 reveals some distinct differences between their monthly values over ER and WR, and their seasonal pattern over the course of the annual 
Table 2. Monthly and seasonal means of $T_{\max }, T h_{n}$, and lightning flash count over $E R$ and WR.

\begin{tabular}{|c|c|c|c|c|c|c|}
\hline & \multicolumn{3}{|c|}{ Eastern region } & \multicolumn{3}{|c|}{ Western region } \\
\hline & $T_{\max }$ & $\mathrm{Th}_{\mathrm{n}}$ & Lightning & $T_{\max }$ & $\mathrm{Th}_{\mathrm{n}}$ & Lightning \\
\hline \multicolumn{7}{|c|}{ Monthly Means } \\
\hline January & 25.2 & 0.5 & 18.2 & 25.8 & 0.4 & 12.5 \\
\hline February & 27.8 & 0.8 & 15.8 & 28.1 & 0.5 & 12.0 \\
\hline March & 32.1 & 2.0 & 103.8 & 32.1 & 1.3 & 34.0 \\
\hline April & 35.6 & 3.5 & 126.6 & 35.2 & 2.7 & 114.2 \\
\hline May & 36.6 & 4.6 & 94.4 & 36.5 & 3.4 & 79.8 \\
\hline June & 34.8 & 6.0 & 122.2 & 34.4 & 3.5 & 73.0 \\
\hline July & 31.8 & 5.3 & 89.4 & 30.8 & 2.8 & 27.6 \\
\hline August & 31.2 & 5.4 & 86.0 & 30.0 & 2.3 & 21.2 \\
\hline September & 31.1 & 5.3 & 127.2 & 30.6 & 2.6 & 66.0 \\
\hline October & 30.8 & 2.3 & 93.8 & 31.0 & 1.9 & 122.4 \\
\hline November & 28.8 & 0.5 & 13.6 & 29.0 & 0.9 & 17.8 \\
\hline December & 25.8 & 0.3 & 3.4 & 26.6 & 0.4 & 5.0 \\
\hline \multirow{3}{*}{\multicolumn{2}{|c|}{$\begin{array}{l}\text { CC } T_{\max }: \mathrm{Th}_{\mathrm{n}} \\
\text { CC } T \mathrm{~h}_{\mathrm{n}}: \text { Lightning } \\
\text { CC } T_{\max } \text { : Lightning }\end{array}$}} & 0.74 & & \multicolumn{3}{|c|}{0.85} \\
\hline & & 0.82 & & \multicolumn{3}{|c|}{0.63} \\
\hline & & 0.84 & & \multicolumn{3}{|c|}{0.73} \\
\hline \multicolumn{7}{|c|}{ Seasonal Means } \\
\hline $\mathrm{JF}$ & 26.5 & 0.7 & 17.0 & 27.0 & 0.5 & 12.0 \\
\hline MAM & 34.8 & 3.4 & 108.0 & 34.6 & 2.5 & 76.0 \\
\hline JJAS & 32.2 & 5.5 & 106.0 & 31.5 & 2.8 & 47.0 \\
\hline OND & 28.5 & 1.0 & 37.0 & 28.9 & 1.1 & 48.0 \\
\hline $\mathrm{CC} T_{\max }: \mathrm{Th}_{\mathrm{n}}$ & \multicolumn{2}{|c|}{0.77} & & & \multicolumn{2}{|l|}{0.87} \\
\hline $\mathrm{CC} \mathrm{Th}_{\mathrm{n}}$ : Lightning & \multicolumn{2}{|c|}{0.91} & & & \multicolumn{2}{|l|}{0.74} \\
\hline $\mathrm{CC} T_{\max }$ : Lightning & \multicolumn{2}{|c|}{0.96} & & & 0.92 & \\
\hline
\end{tabular}

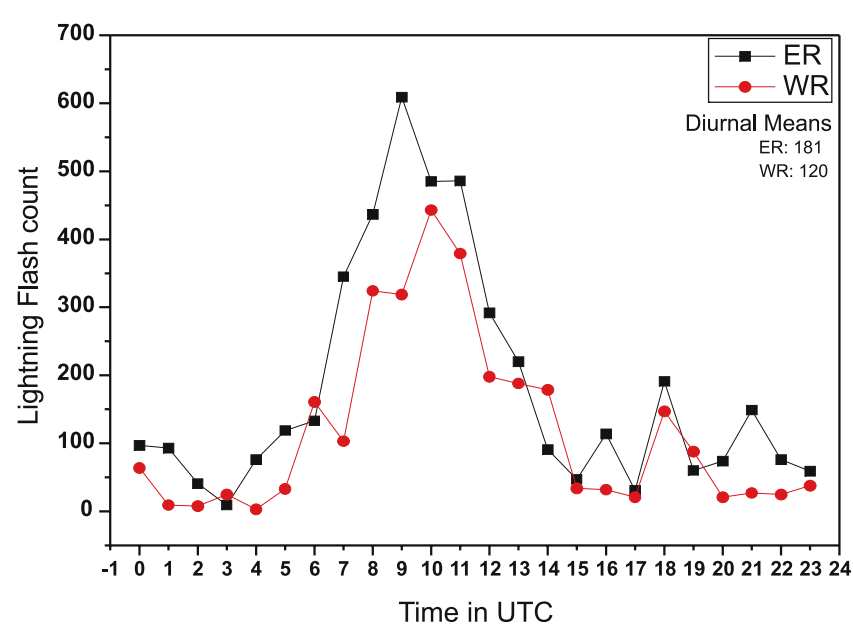

Figure 3. Diurnal variation of hourly mean flash count over ER and WR.

period. We note that during the nine months of January-September, the ER curve lays well above the WR curve and during these nine months, there is a clear preponderance of higher ER values of flash count. During the three months of October-December, WR values are just marginally higher than those of the ER. The seasonal variation over ER is a typical case of monomodal variation. It shows three nearly equal and equispaced maxima, interspersed with two minima. The seasonal variation of the WR is a more clear example of bimodal variation with the first peak in April and the second in October. The seasonal minimum over ER and WR is occurring in the month of August which is coinciding with the climatological singularity in the southwest monsoon rainfall of India (Ananthakrishnan and Pathan 1991). Now, we highlight the aspect of east-west contrast in lightning activity. As we start from the month of January and come upto the month of September, we pass through the three seasons, viz., winter, pre-monsoon and monsoon. It is interesting to note the seasonal trend of flash count during these three seasons. We note that the average excess flash count over ER during January and February months is 5; during March-May months the average excess over ER is 28 and during JuneSeptember months this average excess over ER is 59 flashes. It is important to note that these seasonal average excess values of lightning flash counts over ER are for each month of the season and for each station considered under study. This stepwise seasonal analysis of flash count reveals that as we 
Table 3. Monthly mean maximum wet-bulb potential temperature $\left(T_{\theta w}{ }^{\circ} \mathrm{C}\right)$ during the monsoon months of the years 1972 and 1975 over the ER and WR.

\begin{tabular}{|c|c|c|c|c|c|c|c|c|}
\hline \multirow{3}{*}{ Months } & \multicolumn{4}{|c|}{1972} & \multicolumn{4}{|c|}{1975} \\
\hline & \multicolumn{2}{|c|}{$\begin{array}{c}\text { WR } \\
\text { (results based on } \\
\text { data of } 40 \text { stations) }\end{array}$} & \multicolumn{2}{|c|}{$\begin{array}{c}\text { ER } \\
\text { (results based on } \\
\text { data of } 38 \text { stations) }\end{array}$} & \multicolumn{2}{|c|}{$\begin{array}{c}\text { WR } \\
\text { (results based on } \\
\text { data of } 40 \text { stations) }\end{array}$} & \multicolumn{2}{|c|}{$\begin{array}{c}\text { ER } \\
\text { (results based on } \\
\text { data of } 38 \text { stations) }\end{array}$} \\
\hline & $T_{\theta w}{ }^{\circ} \mathrm{C}$ & $\begin{array}{l}\text { CAPE } \\
(\mathrm{J} / \mathrm{kg})\end{array}$ & $T_{\theta w}{ }^{\circ} \mathrm{C}$ & $\begin{array}{l}\text { CAPE } \\
(\mathrm{J} / \mathrm{kg})\end{array}$ & $\begin{array}{l}\mathrm{CAPE} \\
T_{\theta w}{ }^{\circ} \mathrm{C} \\
\end{array}$ & $(\mathrm{J} / \mathrm{kg})$ & $\begin{array}{l}\text { CAPE } \\
T_{\theta w}{ }^{\circ} \mathrm{C} \\
\end{array}$ & $(\mathrm{J} / \mathrm{kg})$ \\
\hline June & 24.9 & 1950 & 26.2 & 3300 & 24.6 & 1750 & 26.1 & 3200 \\
\hline July & 24.8 & 1800 & 26.3 & 3500 & 24.8 & 1800 & 26.0 & 3150 \\
\hline August & 24.2 & 1150 & 25.9 & 3000 & 24.9 & 1950 & 26.3 & 3500 \\
\hline September & 23.5 & 500 & 25.5 & 2800 & 24.5 & 1600 & 25.9 & 300 \\
\hline
\end{tabular}

move out of the winter season and enter the monsoon season via pre-monsoon season, the ER minus WR contrast widens more and more and becomes extreme around the monsoon season months. Only during the months October-December, the flash count of WR is higher than that over ER. This three months' average excess is 11 flashes while the annual average excess flash count over ER is 25 flashes. The annual mean flash count over ER is 361 and over WR it is 239. Figure 3 shows diurnal variation of hourly totals of flash count over ER and WR. This diurnal value is computed by considering the total five year (1995-1999) period diurnal data of the 40 stations each over ER and WR. It is seen that the ER and WR curves follow each other with striking similarity, but with the difference in flash count such that ER counts are consistently higher during major part of the diurnal period (20/24 h). Moreover, in both the regions, flash count shows a gradual increase from morning hours, attains maximum around $1000 \mathrm{~h}$ (UTC), thereafter it decreases and almost maintains a low-level during the night period. This feature clearly indicates the association between thunderstorm activity (manifestation of moist convection) and flash count over tropical landmass of India. The results of one recent and related study (Manohar and Kesarkar 2003) concerning thunderstorm activity and temperature structure over ER and WR of India showed that the annual total number of thunderstorms over ER are 4763 and over WR are 3194. This study also pointed out that the prominent difference in thunderstorm days over ER was associated during the four months of the monsoon (June-September) season. Further, it was shown that the excess occurrence of thunderstorms over ER was sensitively dependent on the subtle range of excess $T_{\max }\left(0.15-1.2^{\circ} \mathrm{C}\right)$ and higher values of CAPE (Convective Available Potential Energy) over ER (see tables 2 and 3). In an important study (Williams et al 2000) concerning thunderstorms and lightning activity, it was shown that on seasonal and diurnal time-scales, changes in the number of storms dominate the variation in lightning activity by a factor of $2-3$ than the change in the mean flash rate of a storm. It is felt that the above result of ER-WR contrast in lightning activity is a clear manifestation of the east-west contrast in thunderstorm activity over the Indian region.

\subsection{Surface temperature and thermodynamic structure over ER and WR}

In many previous studies (Williams 1992, 1994; Williams et al 1992; Jayaratne 1993; Manohar et al 1999, 2008; Kandalgaonkar et al 2003, 2005a, 2005b, 2006a, 2006b; Manohar and Kesarkar 2003, $2004,2005)$ the use of surface air temperature (both dry- and wet-bulb) as a dependable parameter for studying connection between growth of thunderstorms and their electrical properties (lightning, point discharge current, etc.) has been discussed. Their results have shown high correlation on seasonal time-scales, particularly over tropics. Such an attempt has been made here by comparing the results of lightning flash count with number of thunderstorm days $\left(\mathrm{Th}_{\mathrm{n}}\right)$ and monthly mean maximum surface air temperatures $\left(T_{\max }\right)$ over ER and WR.

Plotted in figure 4 ( $\mathrm{a}$ and $\mathrm{b}$ ) are the monthly mean maximum surface air temperature $\left(T_{\max }\right)$, number of thunderstorm days $\left(\mathrm{Th}_{\mathrm{n}}\right)$, and lightning flash count over ER and WR respectively. Table 2 presents monthly and seasonal mean values of above three parameters over ER and WR for brevity. It may be noted that the correlation coefficients between these $\left(T_{\max }-\mathrm{Th}_{\mathrm{n}}, \mathrm{Th}_{\mathrm{n}}-\right.$ lightning- $T_{\max }$-lightning) parameters over ER and WR based on 12 monthly values are respectively $0.74,0.82,0.84$ and $0.85,0.63,0.73$ which are significant at level of 0.01 . The seasonal correlation coefficients are also highly significant. From figure 4 and table 2 , it can be seen that for an increase in temperature from $25.8^{\circ} \mathrm{C}$ (January) to $36.5^{\circ} \mathrm{C}$ (May), the average lightning flash count increased 

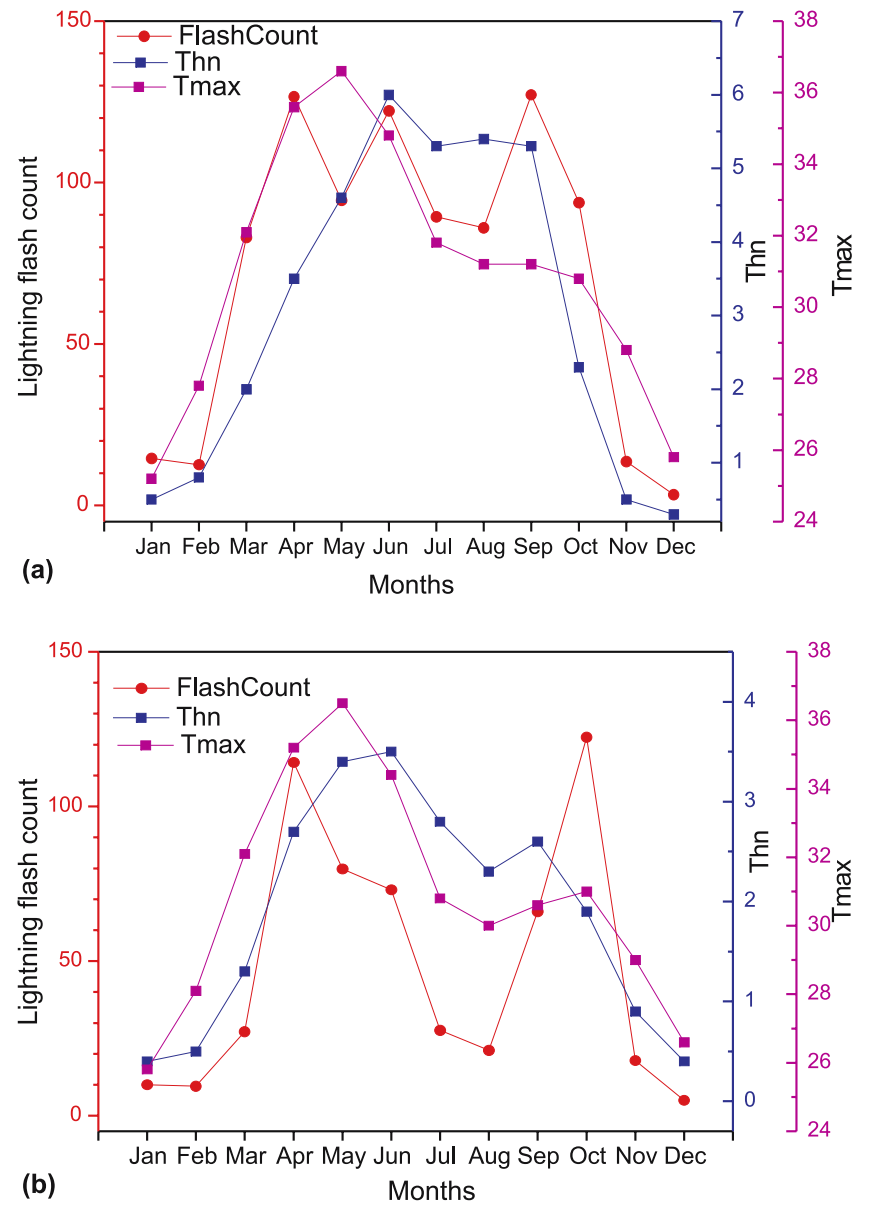

Figure 4. Monthly mean maximum surface air temperature $\left(T_{\max }\right)$, number of (a) and (b) thunderstorm days $\left(\mathrm{Th}_{\mathrm{n}}\right)$, and lightning flash count over ER and WR. $T_{\max }$ and $\mathrm{Th}_{\mathrm{n}}$ results are reproduced from Manohar and Kesarkar (2003).

from 12 to 80 and $\mathrm{Th}_{\mathrm{n}}$ increased from 0.4 to 3.4 for WR. Similar increases in both lightning flash count and $T h_{n}$ with increase in $T_{\max }$ have been noticed for ER also. We thus note the effect of surface maximum air temperature on the development of thunderstorms and hence on lightning activity. The general expectation is that the temperature structure during the monsoon season months over WR must indicate lower values than those over ER. We examined $T_{\theta w}{ }^{\circ} \mathrm{C}$ (wet-bulb potential temperature) and CAPE over ER and WR to supplement this observation (table 3 ). We see that $T_{\theta w}$ as well as CAPE values over WR are systematically lower than those over ER. Reduction in lightning flash count is in agreement with the results of Rutledge et al (1992) concerning electrical output of thunderstorms during two episodes of Australian monsoon.

Studies in the past by Williams et al (1992); Williams (1992, 1994) and Jayaratne (1993) have used the monthly mean maximum wet-bulb temperature to examine its association with deep convection in the tropics (Williams 1997). Also, in an earlier study, Manohar et al (1999) have used the monthly mean maximum values of surface wetbulb temperature to understand the association between wet-bulb temperature and thunderstorm days over the Indian region. In a recent study of spatio-temporal variability of lightning activity over the Indian region, Kandalgaonkar et al (2005b) have documented the role of surface maximum air temperature and showed a pronounced effect of temperature rise in exponential increase in lightning flash density. They have also suggested an approximate increase of 20 to $40 \%$ in lightning flash density for every rise of $1^{\circ} \mathrm{C}$ in surface air temperature. The present observation of reduced lightning activity and reduced number of thunderstorm days over WR, as compared to that over ER, corroborate the results of Manohar and Kesarkar (2003). We note (table 3 ) that the monthly mean maximum wet-bulb potential temperature values during June-September are higher in the range $1.2-2.0^{\circ} \mathrm{C}$ and $\mathrm{CAPE}$ values are as much higher as the CAPE values themselves over ER than those over WR. These results favour the development of frequent and deep convective storms that may produce more lightning over ER. In many studies mentioned at the beginning of this section, the use of wet-bulb $\left(T_{w}\right)$ as well as wet-bulb potential temperature $\left(T_{\theta w}\right)$ has been made to study the connection of this parameter with convective development of thunderstorms and the output of lightning. Wetbulb temperature and its relation with the thermodynamics of air and human comfort has also been studied in the context of the Indian region since long (Normand 1921; Jeevanand Reddy 1976, Doraiswamy 1945). Wet-bulb temperature is a parameter that takes care of moisture or humidity content of the surface atmosphere. The use of wetbulb temperature is consistent because it takes care of temperature and moisture content (humidity) of the atmosphere both of which are important to the thermodynamics of moist convection. Sensitivity results of $T_{w}$ indicated that as $T_{w}$ increased from 25 to $27^{\circ} \mathrm{C}$, lightning count increased by two-fold, while in other case, for a change of $1.9^{\circ} \mathrm{C}$, the lightning activity increased by 20 -fold. These results are representative of land locations situated in the tropics (Williams 1992). These results have produced valid evidence to show the dominance of ER over WR in terms of $\mathrm{Th}_{\mathrm{n}}$ and lightning flash activity. This study corroborates the findings of Rao et al (1971) that there exists an east-west gradient in $\mathrm{Th}_{\mathrm{n}}$ activity over Indian region. This validation of the results requires some more fundamental explanation in terms of other parameters. It is well known that the elevation of land surface above the mean sea level is an important surface property that decides the surface heating of the land region. The lower land regions are systematically 
Table 4. Values of relative cooling in $T_{\max }$, reduction in $T h_{n}$ and lightning flash count over WR with respect to ER during April-September.

\begin{tabular}{lccc}
\hline Months & $\begin{array}{c}\text { Cooling in } T_{\max } \\
\text { ER minus WR }\left({ }^{\circ} \mathrm{C}\right)\end{array}$ & $\begin{array}{c}\text { Reduction in } \mathrm{Th}_{\mathrm{n}} \\
\text { ER minus WR (days) }\end{array}$ & $\begin{array}{c}\text { Reduction in lightning flash } \\
\text { count ER minus WR flash } \\
\text { count (Number) }\end{array}$ \\
\hline April & 0.4 & 0.8 & 12.4 \\
May & 0.1 & 1.2 & 14.6 \\
June & 0.4 & 2.5 & 49.2 \\
July & 1.0 & 2.5 & 61.8 \\
August & 1.2 & 3.1 & 64.8 \\
September & 0.5 & 2.7 & 61.2 \\
Mean & 0.6 & 2.1 & 44.0 \\
\hline CC $T_{\max }:$ Th & & & \\
CC Th $h_{n}:$ Lightning & 0.70 & & \\
CC $T_{\max }:$ Lightning & 0.97 & & \\
\hline
\end{tabular}

hotter than the far elevated ones. Previous study (Manohar and Kesarkar 2003) has shown that the mean altitude of ER is $\sim 313 \mathrm{~m}$ (amsl) and that of the WR is $\sim 580 \mathrm{~m}$ (amsl). This difference in altitude by a factor of about two is an important surface property in maintaining a $T_{\max }$ contrast over ER and WR.

\subsection{Occurrence of thunderstorms and development of lightning in relation to surface temperature}

The occurrence of thunderstorms and development of lightning in relation to temperature change of surface air, on monthly time-scales, has been a topic of long standing interest in many recent studies (Kandalgaonkar et al 2005b and references therein). These studies strongly suggest a close association between surface air temperature and development of thunderstorms. Since lightning originates mainly from thunderstorm clouds, it is also likely that similar relationship should also prevail between these parameters. We have examined one such relationship in this section using the monthly mean data of these parameters over ER and WR. Table 2 provides monthly mean values of $T_{\max }, \mathrm{Th}_{\mathrm{n}}$ and lightning flash count over ER and WR. We see that during January-February months, $T_{\max }$ over WR is higher than over ER. During the period April-September, we see that $T_{\max }$ over ER is higher than over WR. This observation suggests that WR undergoes more cooling relative to ER. This transformation is very systematic and meaningful because there is also simultaneous reduction in $\mathrm{Th}_{\mathrm{n}}$ values over WR. The reduction in $\mathrm{Th}_{\mathrm{n}}$ following the reduction in $T_{\max }$ is explainable on the basis of the reduction in CAPE and reduction in buoyancy of a parcel of air (Price 1993). Table 4 provides the details of the values of relative cooling in $T_{\max }$, reduction in $\mathrm{Th}_{\mathrm{n}}$ and lightning flash count over WR with respect to ER during April-September and correlation coefficients between these parameters.

The mean cooling of $0.6^{\circ} \mathrm{C}$ suggests that for $1^{\circ} \mathrm{C}$ cooling of $T_{\max }$, the reduction in $\mathrm{Th}_{\mathrm{n}}$ works out to be 3.5 and reduction in flash count corresponds to 73 flashes. We note that the $1^{\circ} \mathrm{C}$ cooling in the $T_{\max }$ and associated reduction in number of thunderstorms and lightning flash counts are closely related with each other and are highly significant. The actual range of temperature over which this reduction is based is between $30^{\circ}$ and $36^{\circ} \mathrm{C}$ and the land region corresponds to the complete landmass of WR. This result is in agreement with the results of previous studies mentioned earlier. It is to be noted here that the validity of above result may vary with geography of the location of study, but the generality remains that $\mathrm{Th}_{n}$ and lightning flash count variation is linked with surface maximum air temperature. The changes in the occurrence of thunderstorms dominate or control the variation in lightning activity. This result strongly supports the early results of Williams et al (2000) and signifies the important role of thunderstorms in development of lightning over the tropics.

\subsection{Comparison of monthly mean flash count at different geographic locations representing different climate regimes}

The locations of stations Jaisalmer (JSM), Ahmedabad (AHM), Agartala (AGT), and Guwahati (GHT) are shown in figure 1. JSM and AHM are the two land stations to the NW of India and these two stations represent semi-arid zone climate regime. AGT and GHT are the two land stations in the NE India and these stations represent hilly climate regime. This pair of land stations is chosen for the study because they are situated within $23^{\circ}-27^{\circ} \mathrm{N}$ latitude belt, and their arial distance from the Gulf of Khambhat and 

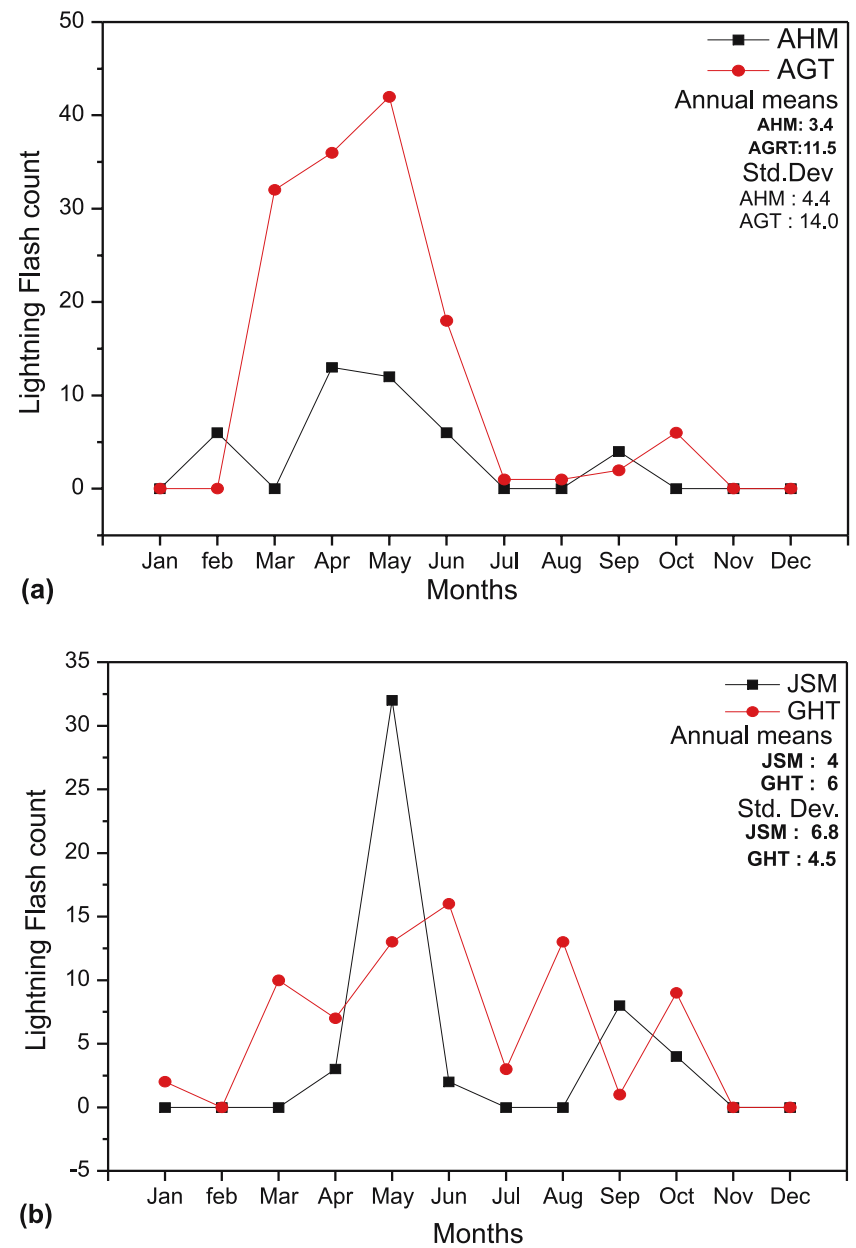

Figure 5. Monthly variation over (a) AHM and AGT (b) JSM and GHT.

Bay of Bengal respectively is nearly the same, i.e., $\sim 350 \mathrm{~km}$. The mean wind direction in the monsoon season from the above-mentioned two sources of water up to these stations is nearly southerly (Rao 1976). An important point of information is that the mean elevation of the semi-arid and hilly regions represented by this pair of stations is much different, and these pairs of stations are $\sim 1100 \mathrm{~km}$ east-west apart from each other.

Figure 5(a and b) shows monthly variation of flash count over AHM, AGT and JSM, GHT. The arid zone locations in both figures represent lower score of lightning than that of the NE hilly region of India. In case of AHM and AGT the pattern of monthly variation is quite comparable. The pattern of monthly variation between JSM and GHT is quite different. Over hot but dry land regions marked by arid-zones, lightning activity is much reduced because the conditions are not favourable for the growth of convective storms. In this comparison, hilly regions, in the vicinity of large source of water, tend to show marked increase in lightning activity. This increase in activity is attributed to the effect of orography in the development of

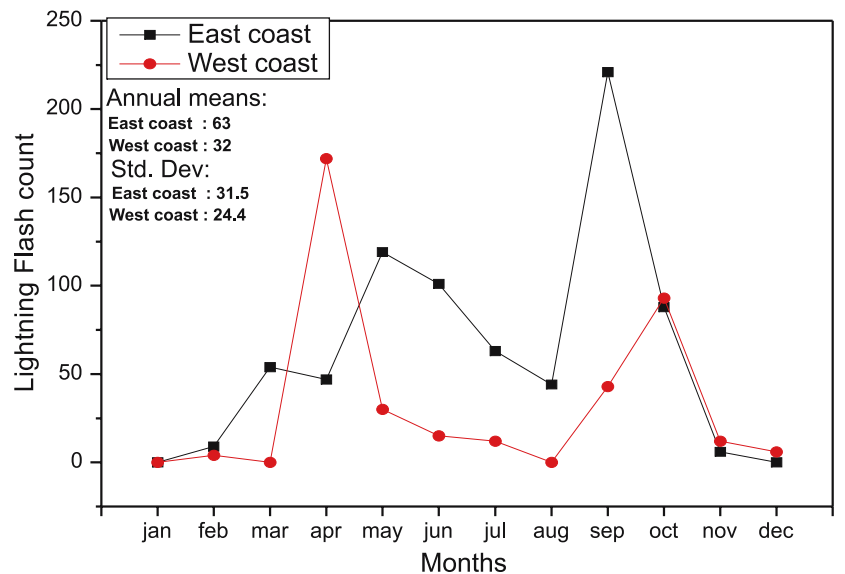

Figure 6. Monthly variation over East and West coasts.

thunderstorms. Irrespective of the fact that there is some similarity and difference in the monthly pattern of lighting flash count between the two pairs of stations: AHM, AGT, and JSM, GHT, the difference found in their annual count over the arid-zone and hilly regions is more alarming. This difference may be explained as follows: Annual frequency of the number of thunderstorm days over a region during a particular year may be a variable number around its climatological mean. But the climatological mean provides a reasonably steady picture of the parameter. We have, therefore, examined the results of recent studies of thunderstorm climatology over India by Pant and Rupakumar (1997) and Manohar and Kesarkar (2004). Their results indicated that the annual frequency of number of thunderstorm days over the arid-zone and hilly regions of NE India varied in the range of 20-30 and 60-80 respectively. Since the best known source of lightning is a thunderstorm cloud, it is reasonable to expect that the difference in lightning flash count will be controlled by the difference in the frequency of thunderstorms (Williams et al 2000).

Figure 6 shows monthly variation in flash count over the east coast and west coast of India. The pattern of monthly variation for both locations indicates bimodal variation but with a difference in the months of their occurrence. In case of west coast, the first peak is pronounced while in the case of east coast the second peak is more pronounced. It is noted here that the annual mean of lightning flash count of east coast is nearly twice higher than that of the west coast. We note that the bimodal variation of lightning flash count over the two coastal belts of India, which lie within the tropics, is analogues with the bimodal oscillation of the number of thunderstorm days (Manohar and Kesarkar 2005). Variations in the incoming shortwave radiation from the sun are attributed to be ultimately responsible for variations in global meteorological parameters on the 

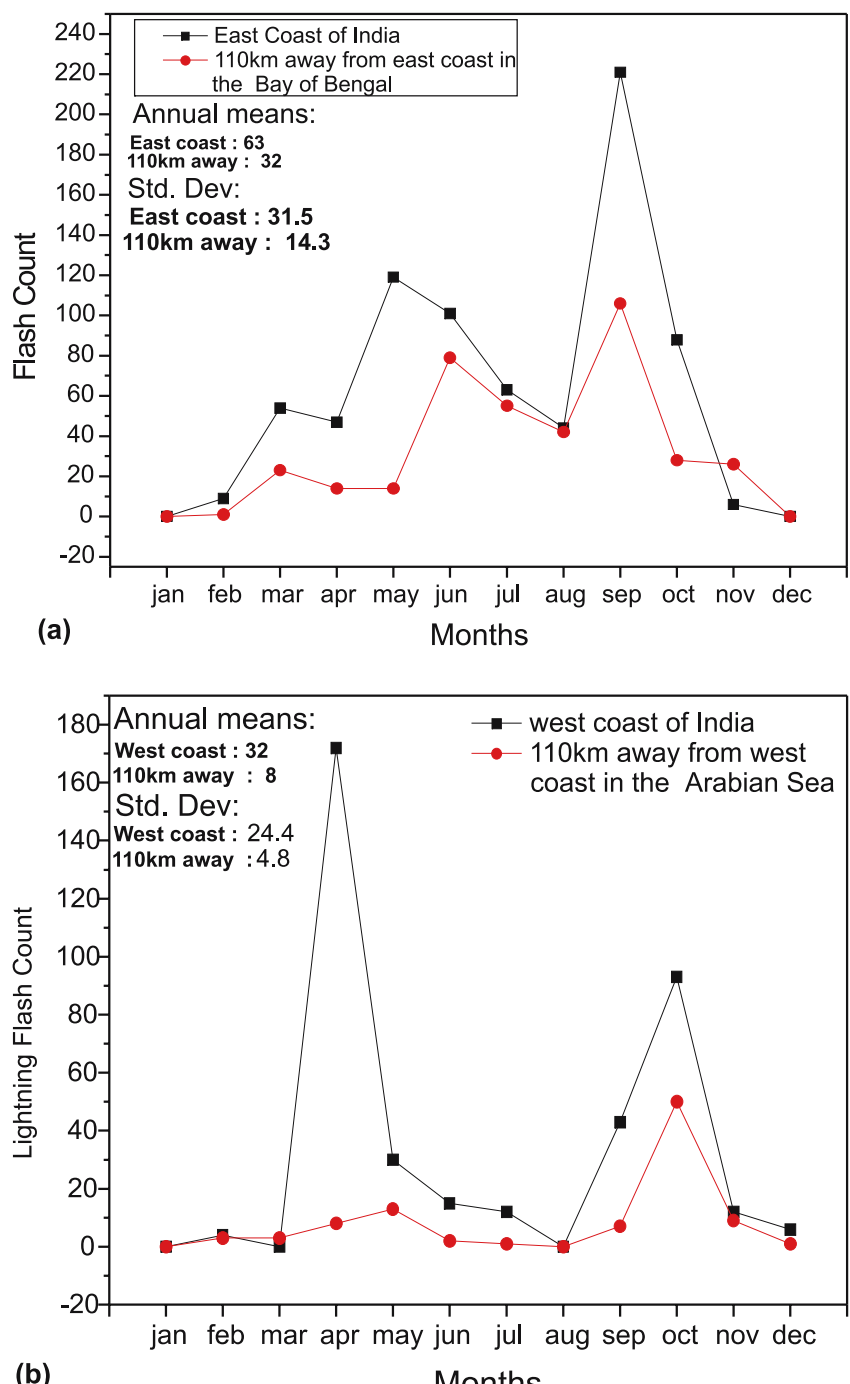

Figure 7. Monthly variation over (a) East coast and a strip of oceanic stations, and (b) West coast and a strip of oceanic stations.

seasonal timescale. From figure 6, we note that during the period June-August, the east coast lightning activity decreases step-wise, and becomes minimum in the month of August. This observation appears to be consistent with the fact that east coast region around the latitude of $15^{\circ} \mathrm{N}$ and south of it, is less dominated by the southwest monsoon. In the months of September and October, lightning activity is picked up. This increase in lightning activity around the months of September and October is believed to be associated with the mark of the postmonsoon season over the stretch of east coast south of $15^{\circ} \mathrm{N}$. In this period, tropical cyclones are formed over the Bay of Bengal. The maximum lightning activity noted may be due to the formation of thunderstorms due to retreating ITCZ and synoptic scale systems (Sikka and Gadgil 1980; Manohar et al 1999; Kandalgaonkar et al 2005).

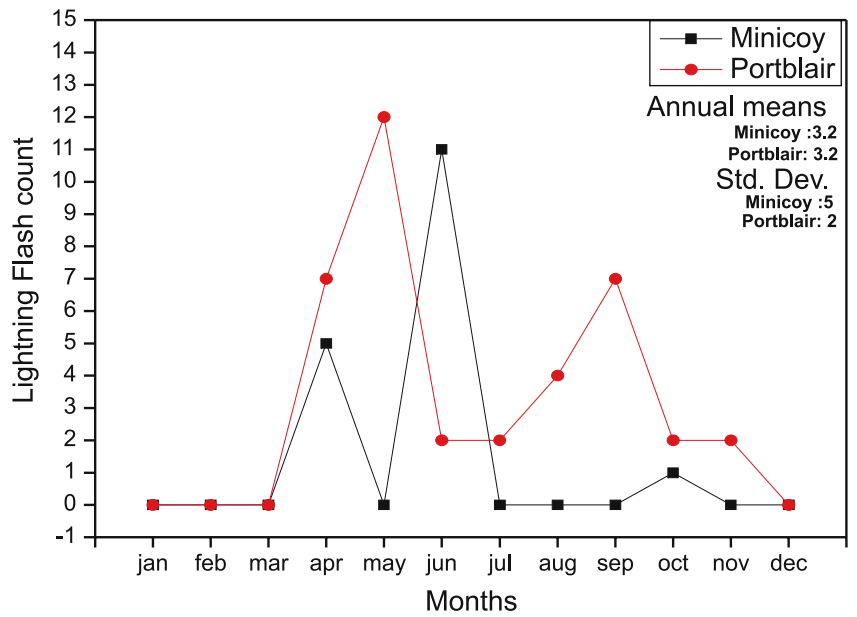

Figure 8. Monthly variation over two island stations (MNC and PBL).

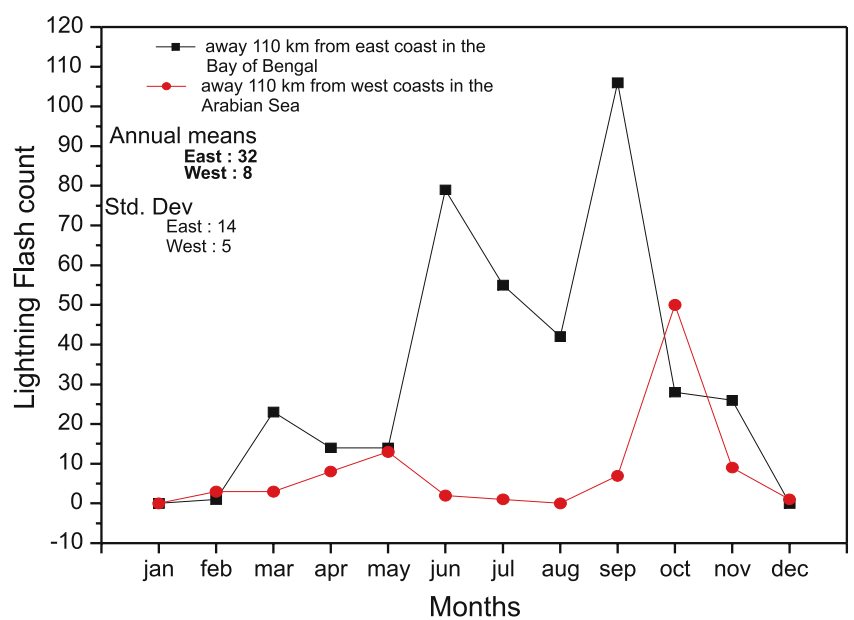

Figure 9. Monthly mean variation of flash count at six pairs of locations representing different climate regimes.

Figure 7 ( $a$ and $b$ ) displays monthly variation in flash count over east and west coasts and over a strip of oceanic stations $110 \mathrm{~km}$ away from them. Two curves in both the figures represent identical pattern of variation but with a clear difference such that east and west coasts score nearly twice or higher activity than that over the oceanic strip $110 \mathrm{~km}$ inside the ocean. An important and notable inference that could be drawn from these observations is that the lightning activity declines by a factor of 2-4 as we move away from the landmass and enter the oceanic climate.

Figure 8 shows variation in flash count over two island stations, one in the Bay of Bengal (PBL) and the other in the Arabian Sea (MNC). We note that the score of both the island stations is same, but the standard deviation of MNC is higher. Shown in figure 9 is the comparison of variation in flash count over the two off-coast oceanic strips. It is very critical and important to note that amongst 
Table 5. Annual mean and standard deviation of lightning flash count at various locations representing different climate regimes.

\begin{tabular}{|c|c|c|c|c|}
\hline \multirow[b]{2}{*}{ Climate regime } & \multicolumn{3}{|c|}{$\begin{array}{c}\text { Annual mean lightning flash count } \\
\text { and no. of stations on which } \\
\text { these means are based }\end{array}$} & \multirow{2}{*}{$\begin{array}{l}\text { Normalized value } \\
\text { of flash count, i.e., } \\
\text { for } 100 \text { stations }\end{array}$} \\
\hline & $\begin{array}{l}\text { Flash } \\
\text { count }\end{array}$ & $\begin{array}{l}\text { Standard } \\
\text { deviation }\end{array}$ & $\begin{array}{l}\text { No. of } \\
\text { stations }\end{array}$ & \\
\hline Continental (ER) & 361 & 173 & 40 & 903 \\
\hline Continental (WR) & 240 & 132 & 40 & 600 \\
\hline Coastal (East coast) & 63 & 32 & 6 & 1050 \\
\hline Coastal (West coast) & 32 & 24 & 6 & 533 \\
\hline Off East coast & 32 & 14 & 6 & 533 \\
\hline Off West coast & 8 & 5 & 6 & 133 \\
\hline $\begin{array}{l}\text { Hilly region of } \mathrm{NE} \\
\text { India (GHT) }\end{array}$ & 6 & 4 & 1 & 600 \\
\hline $\begin{array}{l}\text { Hilly region of NE } \\
\text { India (AGT) }\end{array}$ & 11 & 14 & 1 & 1100 \\
\hline $\begin{array}{l}\text { Semi-arid zone of NW } \\
\text { India (AHM) }\end{array}$ & 3 & 4 & 1 & 400 \\
\hline $\begin{array}{l}\text { Semi-arid zone of NW } \\
\text { India (JSM) }\end{array}$ & 4 & 7 & 1 & 400 \\
\hline Oceanic (MNC) & 3 & 5 & 1 & 320 \\
\hline Oceanic (PBL) & 3 & 2 & 1 & 320 \\
\hline
\end{tabular}

the two oceanic strips, the strip situated $110 \mathrm{~km}$ off the east coast located within the Bay of Bengal has a higher score than that over the strip located within the Arabian Sea. Thus the present study points out that lightning activity tends to increase over tropical moist and hot extensive land regions and as we move out away from the land region into the seas, lightning activity decreases. This property of response of lightning is termed as land-ocean contrast.

For summarizing the contrast in lightning flash count over land and oceanic areas, we provide mean values of key physical parameters which favour strong and weak electrification of the thunderstorms over continents in the tropics and over oceans. From a comprehensive study by Williams and Stanfill (2002), these values are reproduced in the following contingent table:

\begin{tabular}{lcc}
\hline \multicolumn{3}{c}{ Average value } \\
\hline Parameter & Land & Ocean \\
\hline $\begin{array}{l}\text { Surface relative } \\
\text { humidity (\%) }\end{array}$ & $20-60$ & 80 \\
$\begin{array}{c}\text { Cloud base height } \\
(\mathrm{m}, \text { amsl) }\end{array}$ & $1000-4000$ & 500 \\
$\begin{array}{l}\text { Bowen ratio (sensible } \\
\text { heat/latent heat) }\end{array}$ & $0.2-1.0$ & 0.1 \\
$\begin{array}{l}\text { Updraft width (km) } \\
\text { Updraft }\left(\mathrm{ms}^{-1}\right)\end{array}$ & $1-3$ & $0.5-1.0$ \\
\end{tabular}

\subsection{Lightning flash count over different climate regimes}

In the previous section of this study, we have presented results of monthly (January-December) values of lightning flash count at various geographic locations of India. A comparative study of the lightning activity over such locations is presented in this section. Table 5 shows the annual mean and standard deviation of lightning flash count at different climate regimes, and the number of stations on which these means are based. Provided in the last column are the normalized values of flash count at each location.

The normalized annual mean values of flash count are plotted in figure 10 in their ascending order and given serial numbers $1,2,3, \ldots, 12$. At each point of the plot the name of the corresponding climate regime is labelled. A straight line of best fit is drawn through the points. It is clear from the plot that most points lay close to the line on its either side, which implies that there exists a prominent relation between the climate regime and intensity of lightning activity. A close and inquisitive look at the figure indicates that lightning flash count over continents and hilly regions in the tropics is high and its relative measure tends to remain near the upper end of the scale. Lightning activity over areas influenced by dry and marine climatic conditions (semi-arid and island) tends to remain along the central and lower end of the scale. It is felt that long term observations of lightning 


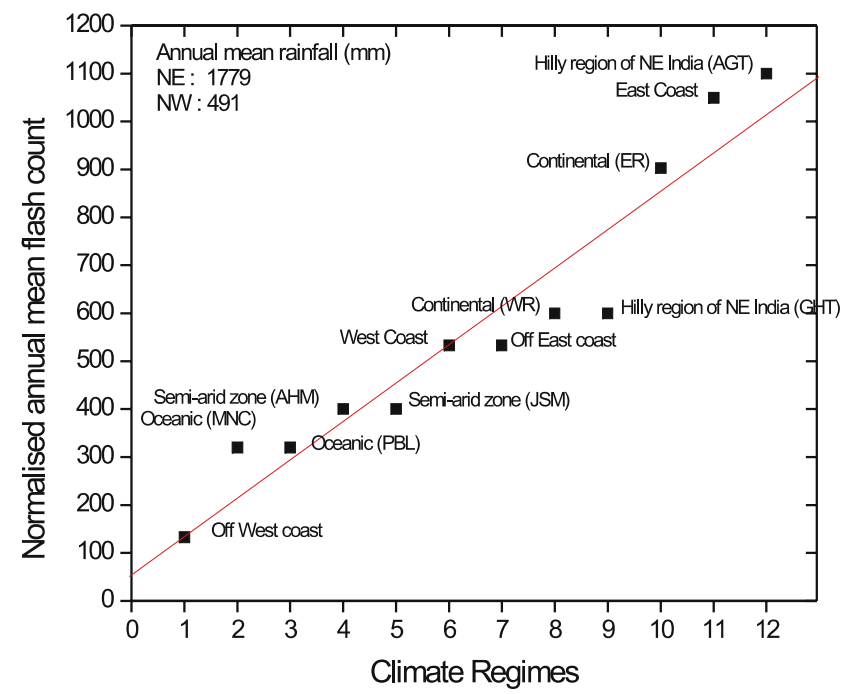

Figure 10. Normalized annual mean values of flash count at locations representing different climate regimes.

at such locations are necessary to arrive at a reasonable and steady picture of this parameter. Some explanation for this observation may be sought in the surface properties such as; lower heat capacity of land, immobile nature of rock-soil, vegetation and topography of a region. As explained by Williams and Stanfill (2002), the land or deep continents in the tropics are systematically hotter and more moist, and hence the lower atmosphere is more unstable to cause vertical air motions. These vertical air motions are usually in excess of $10 \mathrm{~m} / \mathrm{s}$ and are vital for the generation of deep convection or the development of thunderstorms. The effect of mountain ranges (Garo-Khasi and Arakan Yoma to Patkai hills) on the development of thunderstorms in the NE region of India is profound. The Garo-Khasi hills are $300 \mathrm{~km}$ in length and $70 \mathrm{~km}$ in width running east to west. The highest peaks in these ranges of hills are $\sim 2 \mathrm{~km}$ (amsl). The effect of orographic structure, nearness to the Bay of Bengal, and southerly-southwesterly mean wind flow during March-September, on the development of thunderstorms in this area is well known and well described by Rao (1976) and documented in a recent study by Manohar and Kesarkar (2005). Results of a recent study (Chaudhari 2006) concerning the development of thunderstorms over north eastern part of India are important. Their study summarized that CAPE should attain the threshold values of $7000 \mathrm{~J} / \mathrm{kg}$ and CINE (Convective Inhibition Energy) should not exceed $100 \mathrm{~J} / \mathrm{kg}$ respectively for the occurrence of severe thunderstorms. This situation is witnessed quite frequently over NE regions of India during the pre-monsoon season. In the hot but dry environment of the NW India, occupied by deserts and semi-arid zone, annual frequency of thunderstorms is low (less than
$50 \%$ that of the NE region). Storms under such conditions have usually high cloud bases and produce little electrification and precipitation at the ground (Reap 1986). Annual mean rainfall, averaged for the five-year period, 1995-1999 over NE and NW regions of India is also furnished (source: www.tropmet.res.in) in figure 10 to represent the relevance between lightning and rainfall amount. Many studies are devoted to the understanding of oceanic thunderstorms (Zipser 1994; Zipser and Lutz 1994). They suggest that absence of strong (>10 mps) updrafts in the mixed phase region is responsible for the low or near absence of lightning activity in oceanic storms.

\subsection{Sources of errors in lightning flash count and the probable correction}

There could be probable few sources of errors in lightning flash count in this study. A brief discussion on these sources of errors is desirable here. It is felt that due considerations of these errors should be made while taking into account the results of this study. We note that the inbuilt detection efficiency of the OTD system, as mentioned in the literature, is in the range 40-65\% (Christian et al 1996) and 46-69\% (Boccippio et al 2000a). This large range of variation of efficiency depends on various factors such as: external brightness conditions, small-scale nature of weather system, and the polar orbit of the satellite and the simultaneity of the weather event. In this study, we have focused our attention to the comparison of monthly (seasonal) variations of lightning flash count over extended regions of India. Therefore, the overhead absence of the satellite when lightning occurs and the external brightness conditions are the two pertinent causes of worry for the loss of data. Over these causes of loss of data, we do not have any control. In the absence of exact information about the source of error and the correction to be applied, we have not been able to allow for any corrections to our results. It is hard to fix the proper range of correction to the results of this study. However, it is felt that the correction of about $50 \%$ to the results of this study may be appropriate.

\section{Conclusions}

The monthly mean variation of lightning activity, $T_{\max }$, and $\mathrm{Th}_{\mathrm{n}}$ over the two largest adjacent land regions (ER and WR) of India showed remarkable matching between the three parameters. Our analysis showed that as we move out of winter season and enter the monsoon season (MaySeptember); via pre-monsoon season: the WR 
undergoes cooling relative to the ER in the range 0.1 to $1.2^{\circ} \mathrm{C}$. As a consequence, WR experiences reduction in the number of thunder days as well as lowering of flash count. This decrease in $T_{\max }, \mathrm{Th}_{\mathrm{n}}$, and flash count over WR may also be associated with relatively small values of $T_{\max }$ and CAPE in comparison with similar values over ER during the monsoon season. Thus the present study reveals that for cooling of $1^{\circ} \mathrm{C}$ in surface air maximum temperature results in the reduction of $\sim 3.5$ thunderstorms per station and 73 flashes. Summary of the comparison of lightning flashes between pairs of coastal, oceanic, arid-zone, and hilly, and island stations suggests possible relationship between climate regime and intensity of lightning activity. The hilly and deep inland tropical locations are usually placed at the top of the scale than the oceanic and arid-zone areas. Surface properties such as orography, site location, and deep inland placement and nearness to source of water, etc., are primarily responsible for the observed differences noted in the study. We may conclude the results of this study by saying that the overhead lightning activity is a clear reflection of the status of the underlying ground-earth properties. A close and continuous monitoring of lightning activity may be considered as a need of present day scientific studies. More studies are planned for future research to elucidate the observed association between flash count and various meteorological/geographical parameters.

\section{Acknowledgements}

The authors are thankful to the anonymous reviewer for his constructive suggestions. The authors are thankful to the Global Hydrology and Climate Center (GHRC), Huntsville, Alabama for providing the data, and to the Director, IITM for his encouragement. Thanks are also due to Dr P E Raj, Dr B Padmakumari, and Dr S G Narkhedkar for their constructive suggestions in this study.

\section{References}

Aiya S V C 1968 Lightning and power systems; Electrotechnology, Bangalore 12 1-12.

Ananthakrishnan R and Pathan J M 1991 A climatological singularity around mid-August in the summer monsoon rainfall of India; Curr. Sci. $60439-445$.

Boccippio D J, Koshak W, Blakeslee R, Driscoll K, Mach D, Buechler D, Boeck W, Christian H J and Goodman S J 2000a The Optical Transient Detector (OTD): Instrument Characteristics and Cross-Sensor Validation; J Atmos. Ocean Techn. 17 441-458.

Boccipio D J, Goodman S J and Heckman S 2000b Regional differences in tropical lightning observations; J. Appl. Metorol. 39 2231-2248.
Boeck W L, Mach D, Goodman S J, Christian H J Jr. 1999 Optical observations of lightning in Northern India, Himalayan mountain countries and Tibet; Proc. 11th Intl. Conf. on Atmospheric Electricity, Guntersville, AL, ICAE, pp. $420-423$.

Borucki W J and Chameides W L 1984 Lightning - estimates of the rates of energy dissipation and nitrogen fixation; Rev. Geophys. Space Phys. 22 363-372.

Christian H J, Driscoll K T, Goodman S J, Blakeslee R J, Mach D A and Buechler D E 1996 The Optical Transient Detector (OTD); Proc. of the 10th Int. Conf. on Atmospheric Electricity, Osaka, Japan, June 10-14, 1996 , pp. $368-371$.

Chaudhari S 2006 Applicative reasoning to view the prevalence of severe thunderstorms; Mausam 57 523-526.

Doraiswamy Iyer V 1945 India Meteorological Department Technical Note No.11.

Jayaratne E R 1993 Conditional instability and lightning incidence in Gaborone, Botswana; Meteorol. Atmos. Phys. 52 169-175.

Jeevananda Reddy S 1976 Wet-bulb temperature distribution over India; Indian J. Met., Hydro. 85 Geophys. 27 $167-171$.

Jones H L 1958 The identification of lightning discharges by sferic observations; Proc. of the 2nd Conf. on Atmos. Electricity, Portsmouth, NH, Pergamon Press 543-556.

Kandalgaonkar S S, Tinmaker M I R, Kulkarni J R and Asha Nath 2003 Diurnal variation of lightning activity over the Indian region; Geophys. Res. Lett. 30(20) 2022, $2-1$ to $2-5$.

Kandalgaonkar S S, Tinmaker M I R, Nath A S, Kulkarni M K, Trimbake H K 2005(a) Study of thunderstorm and rainfall activity over the Indian region; Atmosfera 18 91-101.

Kandalgaonkar S S, Tinmaker M I R, Kulkarni J R, Nath A S and Kulkarni M K 2005(b) Spatio-temporal variability of lightning activity over the Indian region; J. Geophys. Res. 110 D11108(1-7), 2004JD 005631.

Kandalgaonkar S S, Tinmaker M I R, Kulkarni M K and Nath A S 2006a Lightning and rainfall activity over Gangetic West Bengal; J. Atmospheric Electircity 26 $37-50$.

Kandalgaonkar S S, Tinmaker M I R, Kulkarni M K, Nath A S and Trimbake H K 2006(b) Overview of initial performance of BOLTEK storm tracker: A lightning detector; J. Atmospheric Electircity 26 59-67.

Koshak W J, Blakeslee R J and Bailey J C 2000 Data Retrieval Algorithms for Validating the Optical Transient Detector and the Lightning Imaging Sensor; J. Atmos. Oceanic Techn. 17 279-297.

Malan D J 1958 Radiation from lightning discharges and its relation to the discharge process; Proc. of the 2nd Conf. on Atmos. Electricity, Portsmouth (NH: Pergamon Press) 557-563.

Manohar G K and Kesarkar A P 2003 Climatology of thunderstorm activity over the Indian region: a study of east-west contrast; Mausam 54 819-828.

Manohar G K and Kesarkar A P 2004 Climatology of thunderstorm activity over the Indian region: II. Spatial distribution; Mausam 55 31-40.

Manohar G K and Kesarkar A P 2005 Climatology of thunderstorm activity over the Indian region: III. Latitudinal and seasonal variation; Mausam $\mathbf{5 6}$ 581-592.

Manohar G K and Kandalgaonkar S S 1995 Estimation of electrical changes deposited to the ground by lightning in thunderstorms at Pune; Indian J. Radio Space Phys. 24 297-307. 
Manohar G K, Kandalgaonkar S S and Tinmaker M I R 1999 Thunderstorm activity over India and the Indian southwest monsoon; J. Geophys. Res. 104 4169-4188.

Manohar G K, Kandalgaonkar S S, Tinmaker M I R and Kulkarni M K 2008 A study of seasonal variation of point discharge current during thunder-storms at Pune, India; J. Atmospheric Electricity 28 11-20.

Newcott W R 1993 Lightning; National Geographic 184(1) 80-103.

Nickolaenko A P and Rabinowicz L M 1995 Study of the annual changes of the global lightning distribution and frequency variations of the first Schumann resonance mode; J. Atmos. Terr. Phys. 1345-1348.

Orville R E and Wittenderson R 1986 Global distribution of midlight lightning: December 1997 to August 1978; Mon. Weather Rev. 114 2640-2653.

Normand C W B 1921 Wet-bulb temperature and thermodynamics of air; Ind. Met. Memoirs 23, Part I.

Pant G B and Rupakumar K 1997 Climates of South Asia, John Wiley Publ.

Petersen W A and Rutledge S A 1996 Some characteristics of cloud-to-ground lightning in tropical Northern Australia; J. Geophys. Res. 97 11,553-11,560.

Pradeep Kumar P, Manohar G K and Kandalgaonkar S S 1995 Global distribution of nitric oxide produced by lightning and its seasonal variation; J. Geophys. Res. 100(D6) 11,203-11,208.

Price C 1993 Global surface temperatures and the atmospheric electric circuit; Geophys. Res. Lett. 201363.

Rao K N, Daniel C E J and Balasbramaniam L V 1971 Thudnerstorms over India; IMD Sci. Rep. 153 1-22.

Rao Y P 1976 Southwest Monsoon, in synoptic meteorology; Met. Monogr., 1/1976, India Meteorol. Dept., New Delhi, 86-106.

Reap R M 1986 Evaluation of cloud-to-ground lightning data from the western United States for the 1983-84 summer seasons; J. Climate Appl. Meteor. 25 785-799.

Rutledge S A, Williams E R and Keenan T D 1992 The Down Under Doppler and Electricity Experiment (DUNDEE): Overview and preliminary results; Bull. Am. Meteor. Soc. 73 3-16.
Satori G and Zieger B 1996 Spectral characteristics of Schumann resonances observed in central Europe; J. Geophys. Res. 101(D23) 29,663-29,670.

Schonland B F J 1964 The flight of thunderbolts (Oxford: Clarendon Press), 182 p.

Sikka D R and Gadgil S 1980 On the maximum cloud zone and the ITCZ over India during the southwest monsoon; Mon. Wea. Rev. 108 1840-1853.

Smyth A H (ed.) 1907 The writings of Benjamin Franklin, Macmillan, New York, pp. 421-422.

Williams E R 1985 Large scale charge separation in thunderclouds; J. Geophys. Res. $906013-6025$.

Williams E R 1992 The Schumann resonance: A global tropical thermometer; Science 256 1184-1187.

Williams E R 1994 Global circuit response to seasonal variations in global surface air temperature; Mon. Wea. Rev. 122 1917-1929.

Williams E R 1997 Global circuit response to temperature on distinct time scales: A status report, pl-13, Pearsons Lab., Mass. Inst. of Technol. Cambridge, Mass.

Williams E R, Rothkin K, Stevenson D and Boccippio D 2000 Global lightning variation caused by changes in thunderstorm flash rate and by changes in the number of thunderstorms; J. Appl. Meteorol. 39 2223-2230.

Williams E R, Rutledge S A, Geotis S G, Renno N, Rasmussen E and Rickenbach T 1992 A radar and electrical study of tropical hot towers; J. Atmos. Sci. 49 1386-1395.

Williams E R and Stanfill S 2002 The physical origin of the land-ocean contrast in lightning activity; Appl. Phys. 3 1277-1292.

Workman E J and Reynolds S E 1949 Electrical activity as related to thunderstorm growth; Bull. Am. Meteor. Soc. 30 142-149.

Zipser E J 1994 Deep cumulonimbus cloud systems in the tropics with and without lightning; Mon. Weather Rev. 122 1837-1851.

Zipser E J and Lutz K R 1994 The vertical profile of radar reflectivity of convective cells: A strong indicator of storm intensity and lightning probability, Mon. Weather Rev. 122 1751-1759. 